\title{
Studies on the Effect of Monosodium Glutamate [MSG] Administration on Some Antioxidant Enzymes in the Arterial Tissue of Adult Male Mice
}

\author{
Kuldip SINGH and Pushpa AHLUWALiA* \\ Department of Biochemistry, Panjab University, Chandigarh-160014, India
}

(Received February 25, 2002)

\begin{abstract}
Summary The subcutaneous administration of monosodium glutamate to normal adult male mice at dose levels of 4 and $8 \mathrm{mg} / \mathrm{g}$ body weight caused a significant increase in lipid peroxidation level in the arterial tissue. The levels of total sulfhydryl and protein-bound sulfhydryl groups were found to be significantly increased, whereas non-protein-bound sulfhydryl, representing the glutathione level, was significantly decreased. It was also observed that the administration of monosodium glutamate at a dose level of $4 \mathrm{mg} / \mathrm{g}$ body weight and above induced oxidative stress by significantly lowering the activities of antioxidant enzymes like superoxide dismutases, catalase, and glutathione metabolizing enzymes like glutathione reductase and glutathione peroxidase in the arterial tissue.
\end{abstract}

Key Words monosodium glutamate (MSG), catalase (CAT), lipid peroxidation (LPO), atherosclerosis, oxidative stress.

Monosodium glutamate (MSG) $\left[\mathrm{C}_{5} \mathrm{H}_{8} \mathrm{NO}_{4} \mathrm{NaH}_{2} \mathrm{O}\right]$, a sodium salt of naturally occurring (non essential) Lform glutamic acid, has been used for many years as a flavor enhancer for a variety of foods prepared at home, in restaurants, and by food processors. Its palate pleasing favorite flavor is a must in almost all Chinese, Japanese, and South-Asian dishes $(1,2)$. The interest in the toxicity of MSG as a flavor enhancer has increased due to its association with Chinese restaurant syndrome in human beings $(3,4)$. We have reported previously from our laboratory that the administration of MSG produced hyperlipidemia, hyperglycemia, and hence obesity, which is one of the major factors responsible for the onset of atherosclerosis (5-9).

Atherosclerosis is one of the major causes of death in developing and under-developed countries and is reported to be responsible for about $10 \%$ of the deaths all over the world. This trend has increased about 3-fold in the last decade $(10,11)$. At the threshold of this millennium, atherosclerosis is looming large as a new epidemic. Therefore, immediate attention is needed to prevent this disease.

We have reported previously that MSG induced obesity along with oxidative stress in tissues like erythrocyte and liver. In the present work, we wanted to study the change in oxidative stress upon MSG administration into arterial tissue by studying its effect on some of the antioxidant enzymes such as superoxide dismutase (SOD) and catalase (CAT), and glutathione metabolizing enzymes like glutathione reductase (GR) and glutathione peroxidase (GPx).

\section{MATERIALS AND METHODS}

Animals and treatment. Adult male LAKA-UK mice

\footnotetext{
* To whom correspondence should be addressed.

E-mail: ahluwalap@rediffmail.com
}

weighing 25-30 g were procured from the animal house of Panjab University, Chandigarh, India, and divided into three groups of 25 mice each. MSG was dissolved in water and injected subcutaneously at dose levels of 0,4 , and $8 \mathrm{mg} / \mathrm{g}$ body weight for six consecutive days. Animals were maintained on a rat pellet diet (Hindustan Lever Ltd., Bombay, India) with free access to water. This experimental design was approved by the Animal Experiment Committee of Panjab University, Chandigarh.

Sample preparation. The mice were fasted overnight and sacrificed by decapitation on day 31 after the last injection of MSG because obesity was established after MSG administration for 1 mo $(12,13)$. The arteries were removed, kept on ice, and washed with ice-cold saline. Arteries from five mice were pooled and a 10\% homogenate was prepared in potassium phosphate buffer $(100 \mathrm{~mm}, \mathrm{pH}$ 7.5). The homogenate was centrifuged at $1000 \times \mathrm{g}$ for $15 \mathrm{~min}$ in a cold centrifuge $\left(4^{\circ} \mathrm{C}\right)$. The supernatant was stored at $4^{\circ} \mathrm{C}$ and used for various biochemical assays.

Procedures. The lipid peroxidation (LPO) level in the homogenate was assayed by measuring the pink color chromophore formed by the reaction of thiobarbituric acid with malondialdehye (MDA) according to the method of Hochestein et al. (14). The activities of various antioxidant enzymes like SOD, CAT, GR, and GPx were assayed by the methods of Kono (15), Luck (16), William and Arscott (17), and Necheles et al. (18), respectively. The contents of the total sulfhydryl (T-SH) and non-protein-bound sulfhydryl (NPB-SH) groups were measured using Ellman's reagent by the method of Sedlak and Lindsay (19), and the content of the proteinbound sulfhydryl (PB-SH) group was calculated by subtracting the NPB-SH group from the T-SH group. The level of total protein in the arterial tissue homogenate was assayed by the method of Lowry et al. (20). 
Statistical analysis. Data were analyzed using the Bonferoni " $t$ "-test following ANOVA using MINITAB computer software package. The difference from the control not receiving MSG was considered significant at $p<0.05$.

\section{RESULTS AND DISCUSSION}

The subcutaneous administration of MSG at dose levels of 4 and $8 \mathrm{mg} / \mathrm{g}$ body weight significantly increased the level of malondialdehyde (representing lipid peroxidation) in arterial tissue by 19.5-35.5\% (Table 1). MSG has been reported to induce hyperglycemia (9), which can result in the peroxidation of membrane lipids by increasing the events responsible for glucose oxidation, which in turn promotes NADPH-dependent thiobarbituric acid reactive substances (TBARS) in the presence of cytochrome $\mathrm{P}_{450}(9,21)$.

The increase in LPO level was accompanied by a proportional decrease in the level of NPB-SH group (representing the level of glutathione). In the present study,

Table 1. Effect of subcutaneous administration of MSG for six consecutive days on the level of lipid peroxidation in the arterial tissue of adult male mice (31st d after last injection).

\begin{tabular}{cl}
\hline Group & $\begin{array}{c}\text { Lipid peroxidation } \\
\text { (nmol MDA formed/min/mg protein) }\end{array}$ \\
\hline $\begin{array}{c}\text { I } \\
\text { Control } \\
\text { (0 mg MSG/g b.wt.) }\end{array}$ & $4.17 \pm 0.17^{\mathrm{a}}$ \\
\hline II & \\
\hline (4 mg MSG/g b.wt.) & $\begin{array}{l}4.99 \pm 0.22 \\
(+19.48)^{*}\end{array}$ \\
\hline III & $\begin{array}{l}5.66 \pm 0.16 \\
(8 \mathrm{mg} M S G / g \text { b.wt. })\end{array}$ \\
\hline
\end{tabular}

\footnotetext{
${ }^{a}$ Mean $\pm S D$ of five observations.

Values in parentheses represent percentage change as compared to the control; ${ }^{*} p<0.05$ and ${ }^{* * *} p<0.001$.
}

Table 2. Effect of subcutaneous administration of MSG for six consecutive days on the content of total-sulfhydryl, protein bound-sulfhydryl, and non-protein bound-sulfhydryl groups in the arterial tissue of adult male mice (31st d after last injection).

\begin{tabular}{|c|c|c|c|}
\hline Group & $\begin{array}{l}\text { Total-sulfhydryl } \\
\text { (mmol/g tissue) }\end{array}$ & $\begin{array}{l}\text { Protein bound-sulfhydryl } \\
\text { (mmol/g tissue) }\end{array}$ & $\begin{array}{l}\text { Non-protein bound-sulfhydryl } \\
\quad(\mathrm{mmol} / \mathrm{g} \text { tissue })\end{array}$ \\
\hline $\begin{array}{c}\text { I } \\
\text { Control } \\
(0 \mathrm{mg} \text { MSG/g b.wt. })\end{array}$ & $4.11 \pm 0.16^{\mathrm{a}}$ & $3.72 \pm 0.122$ & $0.170 \pm 0.0035$ \\
\hline $\begin{array}{c}\text { II } \\
\text { (4 mg MSG/g b.wt.) }\end{array}$ & $\begin{array}{l}5.26 \pm 0.120 \\
(+28.1)^{* *}\end{array}$ & $\begin{array}{c}4.74 \pm 0.134 \\
(+27.41)^{* *}\end{array}$ & $\begin{array}{l}0.139 \pm 0.0038 \\
\quad(-18.2)^{*}\end{array}$ \\
\hline $\begin{array}{c}\text { III } \\
(8 \mathrm{mg} \text { MSG/g b.wt.) }\end{array}$ & $\begin{array}{c}5.94 \pm 0.132 \\
(+45.2)^{* * *}\end{array}$ & $\begin{array}{c}5.37 \pm 0.132 \\
(+44.3)^{* * *}\end{array}$ & $\begin{array}{l}0.127 \pm 0.0034 \\
(-25.2)^{* *}\end{array}$ \\
\hline
\end{tabular}

${ }^{\mathrm{a}}$ Mean \pm SD of five observations.

Values in parentheses represent percentage change as compared to the control; ${ }^{*} p<0.05,{ }^{* *} p<0.01$ and ${ }^{* * *} p<0.001$. animals (Table 2). This observation is in agreement with the report that an inverse relationship exists between lipid peroxidation and glutathione status (22). Glutathione depletion to approximately 20-30\% can impair cell defense against the toxic action of xenobiotic, and may lead to cell injury and death $(23,24)$. In the present study, however, animals remained healthy. Thus, it seemed likely that the body tried to protect the cells as the level of T-SH and PB-SH groups was increased by $28-45 \%$ and $27-44 \%$ in groups II and III, respectively (Table 2); glutathione (represented by NPB$\mathrm{SH}$ ) might be used for maintaining the activity of various enzymes, as the level of the NPB-SH group significantly decreased, but the level of the T-SH and PB-SH groups significantly increased.

MSG administration significantly decreased the level of glutathione-metabolizing enzymes like GR and GPx. GPx (a selenium-containing enzyme) inhibits the peroxidation of membrane phospholipids by converting hydroperoxides groups in the phospholipids into corresponding alcohols $(25,26)$. It is conceivable that low activity of GPx may render the tissue more susceptible to LPO damage (27). We observed a significant decrease in the activity of GPx, by $8-15 \%$, in MSG-treated animals upon the increase in LPO level (Table 3). These observations could be in line with the hypothesis that tissue LPO and GPx may play a role in the etiology of atherosclerosis.

A significant decrease of $18-35 \%$ in the activity of GR, a cytosolic enzyme having more affinity for NADPH than NADH, was observed after MSG administration (Table 3). GR is mainly responsible for maintaining glutathione in the reduced state, as it effectively reduces GSSG to GSH by NADPH:GSSG reductase, and hence protects cell against oxygen toxicity (28). The decrease in the activities of GR and GPx could be due to the utilization of more NADPH or increased oxidative stress in the arterial tissue after MSG administration.

A significant decrease in the activity of SOD, a super- was significantly decreased by 18-25\% in MSG-treated 
Table 3. Effect of subcutaneous administration of MSG for six consecutive days on the activities of glutathione reductase and glutathione peroxidase in the arterial tissue of adult male mice (31st d after last injection).

\begin{tabular}{cll}
\hline Group & $\begin{array}{c}\text { Glutathione } \\
\text { reductase } \\
\text { (nmol NADPH } \\
\text { oxidized/min/ } \\
\text { mg protein) }\end{array}$ & $\begin{array}{c}\text { Glutathione } \\
\text { peroxidase } \\
\text { (nmol GSH } \\
\text { oxidized/min/ } \\
\text { mg protein) }\end{array}$ \\
\hline $\begin{array}{c}\text { I } \\
\text { Control }\end{array}$ & $22.0 \pm 0.9^{\text {a }}$ & $20.8 \pm 0.7$ \\
\hline (0 mg MSG/g b.wt). & $\begin{array}{c}18.0 \pm 0.8 \\
(4 \mathrm{mg} \mathrm{MSG/g} \mathrm{b.wt.)}\end{array}$ & $\begin{array}{l}19.0 \pm 0.5 \\
(-18.18)^{*}\end{array}$ \\
\hline $\begin{array}{c}\text { III } \\
(8 \mathrm{mg} \mathrm{MSG} / \mathrm{g} \text { b.wt.) }\end{array}$ & $\begin{array}{c}14.4 \pm 0.8 \\
(-35.45)^{* * *}\end{array}$ & $\begin{array}{l}17.6 \pm 0.5 \\
(-15.38)^{*}\end{array}$ \\
\hline
\end{tabular}

${ }^{\mathrm{a}}$ Mean $\pm \mathrm{SD}$ of five observations.

Values in parentheses represent percentage change as compared to the control; ${ }^{*} p<0.05$ and ${ }^{* * *} p<0.001$.

Table 4. Effect of subcutaneous administration of MSG for six consecutive days on the activities of superoxide dismutase and catalase in the arterial tissue of adult male mice (31st day after last injection).

\begin{tabular}{ccc}
\hline Group & $\begin{array}{c}\text { Total-SOD } \\
\text { (U/mg protein) }\end{array}$ & $\begin{array}{c}\text { Catalase } \\
\text { (nmol of } \mathrm{H}_{2} \mathrm{O}_{2} \\
\text { decomposed } \\
\text { min/mg protein) }\end{array}$ \\
\hline $\begin{array}{c}\text { I } \\
\text { Control }\end{array}$ & $2.95 \pm 0.11^{\mathrm{a}}$ & $4.135 \pm 0.152$ \\
$(0 \mathrm{mg}$ MSG/g b.wt.) & & \\
\hline $\begin{array}{c}\text { II } \\
(4 \mathrm{mg} \text { MSG/g b.wt.) }\end{array}$ & $\begin{array}{c}2.50 \pm 0.09 \\
(-15.50)^{*}\end{array}$ & $\begin{array}{c}3.735 \pm 0.146 \\
(-9.67)\end{array}$ \\
\hline $\begin{array}{c}\text { III } \\
(8 \mathrm{mg} M S G / g \text { b.wt. })\end{array}$ & $\begin{array}{c}2.25 \pm 0.08 \\
(-23.72)^{*}\end{array}$ & $\begin{array}{c}3.404 \pm 0.121 \\
(-17.67)^{* *}\end{array}$ \\
\hline
\end{tabular}

${ }^{\mathrm{a}}$ Mean \pm SD of five observations.

Values in parentheses represent percentage change as compared to the control; ${ }^{*} p<0.05$ and ${ }^{* *} p<0.01$.

oxide scavenging enzyme, by $15.5-23.72 \%$, was observed in MSG-treated groups II and III (Table 4). The presence of SOD in various fractions such as cytosol (CuZn-SOD), mitochondria (Mn-SOD), and plasma (ECSOD) of our bodies enables SOD to dismutate superoxide radicals immediately and protects the cells from oxidative damage (29-31). Although we have not estimated CuZn-SOD and Mn-SOD individually, the decrease in SOD activity suggests that MSG induced neither cytosolic CuZn-SOD nor mitochondrial Mn-SOD.

Catalase, another potent antioxidant enzyme, especially against the superoxide radical and singlet oxygen, was also decreased significantly upon MSG administration (Table 4). Catalase protects cells from the accumu- lation of $\mathrm{H}_{2} \mathrm{O}_{2}$ by dismutating it to form $\mathrm{H}_{2} \mathrm{O}$ and $\mathrm{O}_{2}$, or by using it as an oxidant, in which it works as a peroxidase. Therefoer, the decrease in the activity of catalase by $10-18 \%$ observed in the present study could be due to less availability of NADPH as MSG favors lipogenesis by increasing the level of glutamine (5-8).

All the above observations suggest that MSG administration could cause oxidative stress in the arterial tissue by lowering the activities of SOD, CAT, GR, and GPx, thereby being responsible for the initiation of atherosclerosis.

\section{Acknowledgement}

The authors are grateful to the University Grants Commission for providing financial assistance to conduct this study.

\section{REFERENCES:}

1) Nakashima K, Katsukawa H, Sasmoto K, Ninomiya Y. 2001. Behavioral taste similarities and differences among monosodium L-glutamate and glutamate receptor agonists in C57BL mice. J Nutr Sci Vitaminol 47: 161-166.

2) Geha RS, Beser A, Ren C, Petterson R, Greenberger PA, Grammer LC, Ditto M, Harris KE, Shaughnessy MA, Yarnald PR, Carren J, Saxon A. 2000. Review of alleged reaction to monosodium glutamate and outcome of a multicellular double blind placebo-controlled study. $J$ Nutr 130: 1058S-1062S.

3) Kwok RHM. 1968. Chinese restaurant syndrome. New Eng J Med 278: 796-799.

4) Prawirohard JW, Dwiprahastom I, Astuti I, Hadiwandowo S, Kristin E, Muhammad M, Kelly MF. 2000. The administration to Indonesians of monosodium-L-glutamate in Indonesian foods: an assessment of adverse reactions in a randomized double blind, crossover, placebo-controlled study. J Nutr 130: 1074S-1076S.

5) Ahluwalia P, Malik VBT. 1989. Effect of monosodium glutamate on serum lipids, blood glucose and cholesterol in adult male mice. Toxicol Lett 45: 195-198.

6) Ahluwalia P, and Malik VBT. 1989. Studies on the effect of monosodium glutamate (MSG) on serum lipids and glucose in the presence of normal diet, in adult male mice. Adv Biosci 8: 181-186.

7) Malik VBT, Ahluwalia P. 1994. Studies on the effect of monosodium glutamate (MSG) on various fractions of lipids and certain carbohydrate metabolic enzymes in liver and blood of adult male mice. Toxicol Lett 24: 6977.

8) Ahluwalia P, Tiwari K, Choudhary P. 1996. Studies on the effect of monosodium glutamate (MSG) on oxidative stress in erythrocyte of adult male mice. Toxicol Lett $\mathbf{8 4}$ : 161-165.

9) Choudhary P, Malik VBT, Puri S, Ahluwalia P. 1996. Studies on the effect of monosodium glutamate on hepatic microsomal lipid peroxidation, calcium, ascorbic acid and glutathione and its dependent enzymes in adult male mice. Toxicol Lett 89: 71-76.

10) Lusis AJ. 2000. Atherosclerosis. Atherosclerosis 40: 233-241.

11) Mohindroo A, Ahluwalia P. 1997. Effect of trifluoperazine on certain arterial wall lipid metabolizing enzymes inducing atherosclerosis in Rhesus monkeys. 
Lipids 32: 867-872.

12) Ochi M, Furukawa H, Yoshioka H, Sawada T, Kusuoki T, Hattori T. 1991. Adiposity dynamics in hypothalamic obese mice during food deprivation and refeeding. $J$ Nutr Sci Vitaminol 37: 479-491.

13) Hamaoka K, Kusunoki T. 1986. Morphological and cell proliferative study on the growth of visceral organ in monosodium L-glutamate treated obese mice. J Nutr Sci Vitaminol 32: 395-411.

14) Hochestein P, Nordenbrand K, Ernster L. 1964. Evidence for the involvement of iron in the ADP-activated peroxidation of lipids in microsomes and mitochondria. BBRC 14: 323-328.

15) Kono Y. 1978. Generation of superoxide radical during auto-oxidation of hydroxylamine and an assay for superoxide dismutase. Arch Biochem Biophys 186: 189195.

16) Luck H. 1971. Catalase, method of enzymatic analysis. (Bermeyer HO, ed), p. 855-893. New York Academic Press, London.

17) Williams CHJ, Arscott ID. 1971. Glutathione reductase. In: Methods in Enzymology (Tabor H, Tabor CW, ed), Vol. XVII B, p 503-509. Academic Press, New York and London.

18) Necheles TF, Allen DM. 1968. Erythrocyte glutathione peroxidase deficiency and hemolytic disease of the newborn infant. J Pediatr 22: 319-324.

19) Sedlak J, Lindsay RH. 1968. Estimation of total, protein-bound and non-protein bound-sulfhydryl groups in tissue with Ellman's reagent. Anal Biochem 25: 192205.

20) Lowry DH, Rosenburg NJ, Farr AL, Randall RJ. 1951. Protein measurement with phenol reagent. J Biol Chem 193: $265-275$.

21) Bast A, Haenen GRMM. 1984. Cytochrome P450 and glutathione: what is the significance of their interrelationship in lipid peroxidation. TBS 9: 510-513.

22) Reed DJ, Farris MW. 1984. Glutathione depletion and susceptibility. Pharmacol Rev 36: 25S-33S.

23) Moldeus P, Quanguan J. 1987. Importance of the glutathione cycle in drug metabolism. Pharmacol Ther 33: $37-40$.

24) Meredith MJ, Reed DJ. 1983. Depletion in vitro of mitochondria glutathione in rat hepatocytes and enhancement of lipid peroxidation by adriamycin and 1,3-Bis 2chloroethyl-1nitrosourea (BCNU). Biochem Pharmacol 32: 1383-1388.

25) Gul M, Kutay FZ, Temocin S, Hannien O. 2000. Cellular and clinical implications of glutathione. Ind J Exper Biol 38: $625-634$.

26) Ursini F, Maiorino M, Ferri L, Gregolin C. 1982. Purification from pig liver of a protein which liposomes and biomembrane from peroxidative degradation and exhibits glutathione peroxidase activity on phosphatidyl choline hydroperoxides. Biochem Biophys Acta 710: 197-211.

27) Tsai AC, Thie GM, Lin CR. 1977. Effect of cholesterol feeding on tissue lipid peroxidation, glutathione peroxidase activity and liver microsomal functions in rat and guinea pigs. J Nutr 107: 310-319.

28) Kramar RA, Zakher J, Kim J. 1988. Role of the glutathione redox cycle in acquired and de novo multi drug resistance. Science 24: 694-697.

29) Fridovich I. 1995. Superoxide radical and superoxide dismutase. Annu Rev Biochem 64: 97-112.

30) McCord JM. 1979. Superoxide Dismutase in Isozyme; Current Topics in Biological and Medical Research. Section 1. (Tattozzi MC, Scanalios JG Whitt GS, Alan R, eds), Liss Inc, New York.

31) Marklund SL. 1984. Properties of extracellular superoxide dismutase from human lung. Biochem J 220: 269-272.

32) Krickman HN, Galiiano S, Gaetani GF. 1987. The function of catalase bound NADPH. J Biol Chem 262: 660666. 